\title{
Association between leptin, obesity, hormonal interplay and male infertility
}

Sofia Amjaad

Ziauddin University, Karachi

Mukhtiar Baig

King Abdulaziz University, Jeddah, Saudi Arabia

Nida Zahid

Aga Khan University, nida.zahid@aku.edu

Sundus Tariq

University of Faisalabad, Faisalabad, Pakistan

Rehana Rehman

Aga Khan University, rehana.rehman@aku.edu

Follow this and additional works at: https://ecommons.aku.edu/pakistan_fhs_mc_surg_surg

Part of the Life Sciences Commons, and the Surgery Commons

\section{Recommended Citation}

Amjaad, S., Baig, M., Zahid, N., Tariq, S., Rehman, R. (2019). Association between leptin, obesity, hormonal interplay and male infertility. Andrologia, 51(1), e13147.

Available at: https://ecommons.aku.edu/pakistan_fhs_mc_surg_surg/775 


\title{
Association between leptin, obesity, hormonal interplay and male infertility
}

\author{
Sofia Amjad ${ }^{1}$ | Mukhtiar Baig ${ }^{2}$ | Nida Zahid ${ }^{3}$ | Sundus Tariq ${ }^{4}$ | Rehana Rehman ${ }^{5}$ (D)
}

${ }^{1}$ Department of Physiology, Ziauddin University, Karachi, Pakistan

${ }^{2}$ Department of Clinical Biochemistry, Faculty of Medicine, King Abdulaziz University, Jeddah, Saudi Arabia

${ }^{3}$ Department of Surgery, Aga Khan University, Karachi, Pakistan

${ }^{4}$ Department of Physiology, University Medical and Dental College, the University of Faisalabad, Faisalabad, Pakistan

${ }^{5}$ Department of Biological \& Biomedical Sciences, Aga Khan University, Karachi, Pakistan

\section{Correspondence}

Rehana Rehman, Department of Biological \& Biomedical Sciences, Aga Khan University Karachi, Pakistan.

Email: drrehana7@gmail.com

\begin{abstract}
Male infertility is a major health problem worldwide. We investigated a possible association between leptin, obesity, hormonal interplay and male infertility. This crosssectional study of 313 males (178 infertile and 135 fertile) was carried out in 2017. The subjects were categorised by body mass index (BMI) and body fat percentage (BF\%) into normal weight, overweight and obese. Significantly higher levels of BMI and BF\% ( $p$-value $<0.001$ ) and lower levels of FSH, LH, testosterone, and SHBG ( $p$ value $<0.001$ ) were found in infertile males. However, no significant difference was observed in leptin levels ( $p$-value $=0.35$ ). Leptin levels were significantly higher, and all the sex hormones were significantly lower ( $p$-value $<0.001$ ) in obese subjects, whereas according to BF\% only leptin, FSH and SHBG were significantly different. Leptin showed a significant positive correlation with BMI and BF\% $(p<0.001)$. A strong positive link to serum testosterone was found with age, $\mathrm{FSH}$, and $\mathrm{LH}(p<0.001)$ and a negative one with $\mathrm{BMI}$ and BF\% ( $p<0.001)$. In mutivariable anlaysis, after adjusting for the other covariates, a significant association between FSH and testosterone ( $p$-value $<0.001$ ) was found. Serum leptin levels did not differ significantly in fertile and infertile groups, and no association was found with infertility. Furthermore, male obesity was found to be associated with infertility with the decrease in levels of sex hormones.
\end{abstract}

\section{KEYWORDS}

BMI, leptin, male infertility, obesity, sex hormones

\section{1 | INTRODUCTION}

Infertility is a global problem which has an impact on the physical as well as social well-being of infertile couples (Alam, Khan, \& Rehman, 2018). The male factors account for $20 \%-70 \%$ of infertility problems (Agarwal, Mulgund, Hamada, \& Chyatte, 2015). Obesity is an important issue worldwide that influences fertility as well (Katib, 2015), and the incidence of obesity and infertility has been increasing globally. Various metabolic changes associated with obesity are glucose intolerance, insulin resistance (hyperinsulinemia), hyperleptinemia, chronic inflammation and male hypogonadism (Leisegang, Bouic, Menkveld, \& Henkel, 2014).
Leptin, an adipocyte-secreted protein hormone composed of 167 amino acids, plays multiple functions in the human body, such as regulation of appetite, energy homeostasis and neuroendocrine function (Dalamaga et al., 2013; Park \& Ahima, 2015). Leptin is also an important regulator of male reproduction by modulating the hypothalamus-pituitary-testes (HPT) axis (Leisegang et al., 2014). It has both direct and indirect effects on the HPT axis (Aquila et al., 2005). It acts indirectly via the central neuroendocrine system on the gonadotropin-releasing hormone $(\mathrm{GnRH})$, luteinizing hormone $(\mathrm{LH})$ and follicle-stimulating hormone (FSH). It also has a direct local effect on leydig and sertoli cell function (Lampiao, Agarwal, \& du Plessis, 2009). Serum leptin levels have been found to be high in most obese 
people and rodents with high-fat diet ingestion for a long term (Wang, Zhang, Hu, \& Li, 2018).

Both BMI and serum leptin levels have a positive correlation with abnormal sperm morphology, and a negative correlation with sperm concentration and motility (Einollahi et al., 2016). Hence, this shows a link between obesity and male infertility, mediated by serum leptin. Similarly, Hofny et al. proposed that leptin could transmit direct inhibitory signal for testicular steroidogenesis (Hofny et al., 2010). One of the mechanisms by which leptin affects spermatogenesis is its adverse effect on the transition of the histone to protamine in adult rats during spermatogenesis, which is a reversible process in about 8 weeks (Almabhouh \& Singh, 2018; Almabhouh et al., 2015). Studies have also shown that leptin-induced oxidative stress might be responsible for the decrease in sperm count and abnormal sperm morphology. (Agarwal, Virk, Ong, \& du Plessis, 2014; Almabhouh et al., 2017; Wright, Milne, \& Leeson, 2014). A recent study has also demonstrated the association between male infertility and genetic variability in the leptin gene (Hodžić et al., 2017).

Obesity itself is associated with a reduction in sperm count, sperm motility and abnormal morphology. It has both central and peripheral effects on hypothalamic-pituitary-gonadal axis, resulting in hypogonadotropic hypogonadism. One of the mechanisms of impaired spermatogenesis in obesity is increased testicular temperature due to fat accumulation in the abdominal area, thighs and scrotal area (Kahn \& Brannigan, 2017). In the subjects having a raised $\mathrm{BMI}$, an association was also found with the reduction in testosterone, sperm concentration and oestrogen elevation (Tunc, Bakos, \& Tremellen, 2011). Furthermore, Stewart et al. (2009) reported significant inverse correlations of BMI and obesity with SHBG, inhibin B and testosterone.

A study from Pakistan has reported a significant association between obesity and male infertility (Zahid, Saleem, Azam, \& Moatter, 2015), while another study reported an association between obesity and lower sperm parameters (Hammoud, Gibson, Peterson, Meikle, \& Carrell, 2008). Still, there is a controversy on the effects of $\mathrm{BMI}$ on sperm characteristics and male infertility (Leisegang et al., 2014).

Although the intricate relationship between obesity, leptin and infertility has been investigated a number of times, their causal relationship has not been elucidated. The present study investigated the association between serum leptin and male infertility and further investigated the impact of obesity and reproductive hormones on male fertility.

\section{2 | MATERIAL AND METHODS}

We conducted a cross-sectional study, and after taking a written informed consent from the study participants, the infertile patients were recruited from infertility clinic in Islamabad while the fertile patients were recruited from general population through individual contacts. The sample size was calculated in
Open Epi software version 3 based on the formula: $n=(Z \alpha+Z \beta)^{2}$ $\left(o^{\prime} 1^{2}+\sigma^{\prime} 2^{2}\right) /^{2}$. We required a minimum sample size of 220 patients in order to achieve $80 \%$ power, with an anticipated difference in mean leptin levels among fertile and infertile males of -1.5 (Von Sobbe, Koebnick, Jenne, \& Kiesewetter, 2003) and a level of significance of $5 \%$. We were successful in achieving a sample size of 313 patients for analysis.

The fertility status of study participants in our study was based on semen parameters according to (WHO criteria "2010") that is "sperm concentration of $>20$ million $/ \mathrm{ml}$, semen volume of $>2 \mathrm{ml}$, motility of $>50 \%$, and morphology of $>30 \%$ was considered normal" (Menkveld et al., 2001). Infertile patients were men with impaired semen parameters and fertile were men who did not have impaired semen parameters. The inclusion criteria for both the fertile and infertile were as follows: subjects aged $20-55$ years and who gave consent to participate in the study.

The exclusion criteria for both the fertile and infertile males were as follows: subjects with varicocele or hyperlipidemia, who were taking a steroid or had any chronic disease (e.g., liver/renal disease, hypertension, cardiovascular disease, diabetes, and thyroid disorder).

The institutional Ethics Review Committee of Islamabad Clinic Serving Infertile Couples (256-ICSFC-REC-16) granted the ethical approval for this study. Written consent was taken from all the study participants.

All the data regarding the medical history and physical examination were taken. The height and weight of all the subjects were measured to calculate $\mathrm{BMI}$, and $\mathrm{BF} \%$ was measured by a bioelectrical impedance analyzer. Bioelectrical impedance analyzer (BIA) was used for measuring the percentage of body fat of the participants. Bioelectric impedance analyzer is a safe, non-invasive and portable device used for assessing body fat composition from the estimate of entire body water. Foot-to-foot (FF) BIA scales are much more convenient and are recently being used since the subject only needs to stand without shoes on the scale for simultaneous measurements of BW (body weight) and impedance across the lower limbs. Gender, age and height are entered manually into the system by a digital keyboard, and the fat mass (FM) of the subject or percentage fat mass (\% FM) is displayed immediately (Lazzer, Boirie, Meyer, \& Vermorel, 2003).

The BMI of the study participants was measured and categorised according to the cut-offs for Asians, the normal weight (18-22.9 kg/ $\left.\mathrm{m}^{2}\right)$, overweight $\left(23-24.9 \mathrm{~kg} / \mathrm{m}^{2}\right)$ and obesity $\left(\geq 25 \mathrm{~kg} / \mathrm{m}^{2}\right)(\mathrm{WHO}$, 2004). The cut-offs used for BF\% were normal weight (12\%-22\%), overweight (22.1\%-27\%) and obese (>27.1\%) (Zahid et al., 2015).

Blood samples were drawn in sterile syringes by venous puncture, and serum was kept at $-80^{\circ} \mathrm{C}$ for hormonal analysis. The serum levels of testosterone, $\mathrm{LH}$, and FSH were assayed by Enzyme Immunoassay EIA kits (Amgenix International.Inc, USA). For leptin determination, EIA kit (AssayMax, Germany) was used, and SHBG was measured by the Elecsys ${ }^{\circledR}$ electrochemiluminescence platform-based immunoassay (Roche Diagnostics, Indianapolis, IN). The manufacturer's protocol was followed for the detection of hormones. 
TABLE 1 Clinical, biochemical and semen characteristic of fertile and infertile males

\begin{tabular}{|c|c|c|c|}
\hline Factors & Infertile $(n=178)$ & Fertile $(n=135)$ & $p$-Value \\
\hline Leptin (ng/ml), Mean $\pm S D$ & $12.62 \pm 6.74$ & $12.00 \pm 5.05$ & 0.359 \\
\hline Age (years), Mean $\pm S D$ & $33.74 \pm 5.67$ & $37.65 \pm 6.12$ & $<0.001^{*}$ \\
\hline $\mathrm{FSH}(\mathrm{mlU} / \mathrm{ml})$, Mean $\pm S D$ & $3.41 \pm 1.97$ & $6.31 \pm 2.50$ & $<0.001^{*}$ \\
\hline $\mathrm{LH}(\mathrm{mlU} / \mathrm{ml})$, Mean $\pm \mathrm{SD}$ & $5.45 \pm 2.90$ & $9.96 \pm 2.58$ & $<0.001^{*}$ \\
\hline Testosterone (ng/ml), Mean $\pm S D$ & $3.35 \pm 1.92$ & $8.16 \pm 1.38$ & $<0.001^{*}$ \\
\hline \multicolumn{4}{|l|}{ BMI (in $\mathrm{kg} / \mathrm{m}^{2}$ ) } \\
\hline Normal weight (18-22.9) & $28(15.7 \%)$ & $41(30.4 \%)$ & \multirow[t]{3}{*}{$<0.001^{*}$} \\
\hline Overweight (23-24.9) & $25(14.0 \%)$ & $27(20.0 \%)$ & \\
\hline Obese $(\geq 25)$ & $125(70.2 \%)$ & $67(49.6 \%)$ & \\
\hline BMI (Mean $\pm S D)$ & $26.67 \pm 3.59$ & $24.76 \pm 3.08$ & $<0.001^{*}$ \\
\hline BF (\%), Mean $\pm S D$ & $34.37 \pm 4.66$ & $32.97 \pm 4.06$ & $0.006^{*}$ \\
\hline SHBG Median (IQR) & $15.44(12.06-18.95)$ & $32.06(25.98-30.71)$ & $<0.001^{*}$ \\
\hline $\begin{array}{l}\text { Total sperm Count (TC Millions/ } \\
\text { ml), Mean } \pm S D\end{array}$ & $73.86 \pm 57.087$ & $95.42 \pm 48.472$ & $<0.001^{*}$ \\
\hline Percentage motility (Mean $\pm S D$ ) & $52.82 \pm 26.976$ & $65.21 \pm 14.794$ & $<0.001^{*}$ \\
\hline $\begin{array}{l}\text { Rapid linear progression } \\
(\text { Mean } \pm S D)\end{array}$ & $1.37 \pm 5.050$ & $1.75 \pm 5.747$ & 0.54 \\
\hline $\begin{array}{l}\text { Percentage Normal morphology } \\
(\text { Mean } \pm S D)\end{array}$ & $4.84 \pm 4.20$ & $6.12 \pm 4.00$ & $0.007^{*}$ \\
\hline
\end{tabular}

*Significant at $p$ value $<0.05$
Data were analysed on the Statistical Package for the Social Sciences (version 22.0). The categorical variables are represented by frequencies and percentages while quantitative variables by means and standard deviations/median (IQR). Hormonal levels were assessed in three groups of BMI and BF\% by using one-way ANOVA for normally distributed quantitative variables (such as age, $\mathrm{FSH}, \mathrm{LH}$ and testosterone), and the Kruskal-Wallis test for non-normally distributed quantitative variables (such as SBHG). The correlation coefficient was assessed between quantitative variables by Pearson correlation (for normally distributed data) and Spearman correlation (for non-normally distributed data). Unadjusted and adjusted prevalence ratio (PR) with $95 \%$ confidence intervals (Cls) was reported by using Cox Proportional Hazard Algorithm. The statistical significance was considered at $p$-value $<0.05$.

\section{3 | RESULTS}

The baseline characteristics of fertile and infertile males are given in Table 1. About two-thirds (70\%) of the infertile males were obese as compared to the fertile males (49\%). Similarly, the mean BF\% was also significantly higher among infertile males as compared to fertile males ( $p$-value <0.001). Serum leptin levels in fertile and infertile subjects were not significantly different ( $p$-value $=0.36$ ). The mean values of $\mathrm{FSH}, \mathrm{LH}$, testosterone and median SHBG were significantly higher ( $p$-value $<0.001$ ) in the fertile group as compared to the infertile group. The mean total sperm count, motility and normal morphology were significantly higher among the fertile group as compared to the infertile group ( $p$-value $<0.001$ ). In the infertile group, 96 (71.1\%) males were smokers, while in the fertile group 140 (78.8\%) were smokers $(p=0.117)$.

Leptin levels were higher while FSH, LH, testosterone and median (IQR) SHBG concentrations were significantly lower in obese men ( $p$-value $<0.001$ ) as compared to normal weight and overweight men. About $65 \%$ of infertile men were obese as compared to $35 \%$ of fertile males ( $p$-value $<0.001$; Table 2).

A comparison of the clinical and biochemical data according to $\mathrm{BF} \%$ of the participants is made in Table 3. According to BF\%, 25 (8\%) participants were overweight $(\mathrm{BF}=22.1 \%-27 \%)$ and $288(92 \%)$ were obese ( $B F \geq 27.1 \%$ ).

A significant positive correlation of serum leptin was found with BMI $(p<0.001)$, body fat percentage $(p<0.001)$ and a negative correlation with $\mathrm{FSH}(p=0.002)$. However, the non-significant negative correlation was found between leptin and testosterone $(p=0.096)$. A strong positive link of serum testosterone was found with age, $\mathrm{FSH}$, and $\mathrm{LH}(p<0.001)$ and negative with BMI and BF\% ( $p<0.001$; Table 4).

Our results showed no significant association between leptin and infertility on univariate and multivariate analysis. Moreover, with every one-unit increase in age, $\mathrm{FSH}, \mathrm{LH}$, testosterone and SHBG, the chances of being infertile decreased significantly by $4.7 \%, 20 \%, 15.7 \%, 22.4 \%$ and $6.9 \%$, respectively. It was also observed that with one-unit rise in BMI the chances of being infertile increased by $6.9 \%$, and with every unit increase in $\mathrm{BF} \%$, the chances of being infertile increased by $3.1 \%$. The obese males were 1.604 times more likely to be infertile as compared to normal weight (Table 5).

In multivariate analysis, there was a significant relationship between FSH and testosterone at $p$-value $<0.001$. Hence, with every 


\begin{tabular}{|c|c|c|c|c|}
\hline \multirow{2}{*}{ Variables } & \multicolumn{4}{|c|}{ BMI status (in $\mathrm{kg} / \mathrm{m}^{2}$ ) } \\
\hline & $\begin{array}{l}\text { Normal weight } \\
(18-22.9) \\
n=69\end{array}$ & $\begin{array}{l}\text { Over weight } \\
(23-24.9) \\
n=52\end{array}$ & $\begin{array}{l}\text { Obese }(\geq 25) \\
n=192\end{array}$ & $p$ Value \\
\hline Leptin $(\mathrm{ng} / \mathrm{ml})$, Mean $\pm S D$ & $6.16 \pm 3.22$ & $9.22 \pm 5.26$ & $15.43 \pm 4.81$ & $<0.001^{*}$ \\
\hline Age (years), Mean $\pm S D$ & $34.97 \pm 6.30$ & $35.21 \pm 6.16$ & $35.65 \pm 6.15$ & $0.709^{*}$ \\
\hline $\mathrm{FSH}(\mathrm{mlU} / \mathrm{ml})$, Mean $\pm \mathrm{SD}$ & $5.82 \pm 3.06$ & $5.16 \pm 2.44$ & $4.12 \pm 2.36$ & $<0.001^{*}$ \\
\hline $\mathrm{LH}(\mathrm{mlU} / \mathrm{ml})$, Mean $\pm S D$ & $8.32 \pm 3.25$ & $8.56 \pm 3.45$ & $6.75 \pm 3.55$ & $<0.001^{*}$ \\
\hline $\begin{array}{l}\text { Testosterone }(\mathrm{ng} / \mathrm{ml}) \text {, } \\
\text { Mean } \pm S D\end{array}$ & $6.38 \pm 2.83$ & $6.34 \pm 2.63$ & $4.83(2.90)$ & $<0.001^{*}$ \\
\hline Body fat (\%) & $27.99 \pm 2.49$ & $31.47 \pm 1.52$ & $36.45 \pm 2.98$ & $<0.001^{*}$ \\
\hline SBHG Median(IQR) & $23.955 \pm 3.18$ & $24.02 \pm 23.92$ & $18.95 \pm 12.43$ & $<0.001^{*}$ \\
\hline \multicolumn{5}{|l|}{ Fertility status $=n(\%)$} \\
\hline Infertile & $28(40.6)$ & $25(48.1)$ & $125(65.1)$ & $<0.001^{*}$ \\
\hline Fertile & $41(59.4)$ & 27 (51.9) & $67(34.9)$ & \\
\hline
\end{tabular}

*Significant at $p$ value $<0.05$

\begin{tabular}{|c|c|c|c|}
\hline \multirow[b]{2}{*}{ Variables } & \multicolumn{3}{|l|}{ Body fat $\%$} \\
\hline & $\begin{array}{l}\text { Over weight }(n=25) \\
(22.1 \%-27 \%)\end{array}$ & $\begin{array}{l}\text { Obese }(n=288) \\
(\geq 27.1 \%)\end{array}$ & $p$ Value \\
\hline Leptin (ng/ml), Mean $\pm S D$ & $5.30 \pm 3.32$ & $12.94 \pm 5.91$ & $<0.001^{*}$ \\
\hline Age (years), Mean $\pm S D$ & $31.95 \pm 3.61$ & $35.72 \pm 6.23$ & $<0.001^{*}$ \\
\hline \multicolumn{4}{|l|}{$\mathrm{BMI}\left(\mathrm{kg} / \mathrm{m}^{2}\right)$} \\
\hline Normal weight (18-22.9) & $25(100)$ & $44(15.3)$ & \multirow[t]{3}{*}{$<0.001$} \\
\hline Overweight (23-24.9) & 0 & $52(18.1)$ & \\
\hline Obese $(\geq 25)$ & 0 & $192(66.7)$ & \\
\hline BMI $\left(\mathrm{kg} / \mathrm{m}^{2}\right)$, Mean $\pm S D$ & $19.47 \pm 0.98$ & $26.40 \pm 3.09$ & \\
\hline $\mathrm{FSH}(\mathrm{mlU} / \mathrm{ml})$, Mean $\pm S D$ & $6.20 \pm 3.19$ & $4.53 \pm 2.54$ & $0.004^{*}$ \\
\hline $\mathrm{LH}(\mathrm{mlU} / \mathrm{ml})$, Mean $\pm S D$ & $7.53 \pm 3.23$ & $7.34 \pm 3.55$ & 0.812 \\
\hline $\begin{array}{l}\text { Testosterone }(\mathrm{ng} / \mathrm{ml}) \\
\text { Mean } \pm S D\end{array}$ & $6.15 \pm 3.15$ & $5.34 \pm 2.90$ & 0.208 \\
\hline SBHG Median (IQR) & $25.98 \pm 54.73$ & $20.77 \pm 15.81$ & 0.198 \\
\hline \multicolumn{4}{|l|}{ Fertility status } \\
\hline Infertile & $10(40.0)$ & $168(58.3)$ & \multirow[t]{2}{*}{0.093} \\
\hline Fertile & $15(60.0)$ & $120(41.7)$ & \\
\hline
\end{tabular}

${ }^{*}$ Significant at $p$ value $<0.05$

\begin{tabular}{|c|c|c|}
\hline Variables & $\begin{array}{l}\text { Correlation coefficient of serum } \\
\text { leptin } \\
r(p \text {-value })\end{array}$ & $\begin{array}{l}\text { Correlation coefficient of serum } \\
\text { testosterone } \\
r \text { ( } p \text {-value) }\end{array}$ \\
\hline Age & $0.145(0.01)$ & $0.243(<0.001)$ \\
\hline $\mathrm{BMI}$ & $0.572(<001)$ & $-0.288(<0.001)$ \\
\hline FSH & $0.179(0.002)$ & $0.472(<0.001)$ \\
\hline LH & $-0.066(0.243)$ & $0.903(<0.001)$ \\
\hline Testosterone & $-0.094(0.096)$ & 1 \\
\hline $\mathrm{BF}$ & $0.585(<0.001)$ & $-0.194(<0.001)$ \\
\hline Leptin & 1 & $-0.094(0.096)$ \\
\hline
\end{tabular}

Note. r: Correlation coefficient.
TAB LE 2 Clinical and biochemical data analysis between the groups based on the $\mathrm{BMI}$ status of the study participants

TAB LE 3 Comparison of the clinical and biochemical data according to Body fat $\%$ of the participants

TA B LE 4 Correlation of serum leptin and testosterone with other variables 
TAB LE 5 Univariate analysis for clinical and biochemical factors associated with male infertility

\begin{tabular}{|c|c|c|c|}
\hline Factors & $\begin{array}{l}\text { Unadjusted Prevalence } \\
\text { Ratio (PR) }\end{array}$ & $95 \% \mathrm{Cl}$ & $p$ Value \\
\hline Leptin (ng/ml) & 1.007 & $0.983-1.032$ & 0.558 \\
\hline Age (in years) & 0.953 & $0.929-0.978$ & $<0.001^{*}$ \\
\hline FSH (in mlU/ml) & 0.796 & $0.740-0.855$ & $<0.001^{*}$ \\
\hline LH (in mIU/ml) & 0.843 & $0.805-0.882$ & $<0.001^{*}$ \\
\hline Testosterone (in ng/ml) & 0.776 & $0.735-0.820$ & $<0.001$. $^{*}$ \\
\hline \multicolumn{4}{|l|}{ BMI (in kg/m²) } \\
\hline Normal weight (18-22.9) & 1 & & $0.047^{*}$ \\
\hline Overweight (23-24.9) & 1.185 & $0.691-2.032$ & \\
\hline Obese $(\geq 25)$ & 1.604 & $1.065-2.417$ & \\
\hline BMI & 1.069 & $1.026-1.114$ & $0.002^{*}$ \\
\hline BF (\%) & 1.031 & $0.998-1.066$ & $0.07^{*}$ \\
\hline SHBG & 0.931 & $0.912-0.950$ & $<0.001^{*}$ \\
\hline
\end{tabular}

*Significant at $p$ value $<0.25$ one-unit increase in testosterone, the FSH led to a 5.2\% decrease in infertility. Therefore, testosterone interacted with FSH in its effect on infertility (Table 6).

\section{4 | DISCUSSION}

Male fertility has been linked to leptin by a number of studies but the exact causal relationship has not been established. Risk factors like obesity are a rising epidemic in men of reproductive age and are not only causing but also aggravating infertility.

Our results showed no significant difference in serum leptin level in the fertile and infertile groups. In contrast to our results, few studies have reported higher leptin levels in infertile male patients (Farooq, Lutfullah, \& Ahmed, 2014; Jahan, Bibi, Ahmed, \& Kafeel, 2011) while few other studies demonstrated results similar to our study (Dayer, Nikbakht, \& Elyaderani, 2013; Tafvizi \& Masomi, 2016). The inconsistency of results could be due to the difference in sample size, the use of different kits and variation in the dietary customs and lifestyles of different nations (Tafvizi \& Masomi, 2016).

The absence of significant difference in serum leptin levels in both groups shows that serum leptin is not involved in the process of fertility among male subjects. However, it is possible that by some indirect mechanism it may influence the process of fertility.
In this study, both BMI and BF\% are observed to be significantly higher in infertile males as compared to fertile males. Obesity influences male fertility through various mechanisms, which include obesity-related hypogonadism, reduced spermatogenesis and erectile dysfunction (Chambers \& Richard, 2015). In our study, obese individuals exhibited a decrease in testosterone levels. This finding can be explained based on the fact that in obese subjects there is more aromatase activity that converts testosterone to estradiol, thus causing hypoandrogenemia and increased oestrogen levels that change the negative feedback system in hypothalamic and pituitary area (Akinloye \& Truter, 2011; Chambers \& Richard, 2015).

Our results showed that serum leptin concentrations were significantly higher and the values of FSH, LH, testosterone and SHBG were significantly lower in obese men as compared to normal-weight and overweight men. These results are consistent with another study, which connect the leptin and sex hormones in obese infertile males (Farooq, Ullah, \& Ishaq, 2013). It is possible that leptin inhibits steroid production in testicles that elucidate the link between hyperleptinemia, decreased gonadotrophins and testosterone production in obese males, as has been documented (Hausman, Barb, \& Lents, 2012; Hofny et al., 2010).

The current study has shown a significant positive relationship of leptin with BMI and BF\%. Other studies have also reported a positive correlation of BMI with leptin levels (Farooq et al., 2014). Also, we found that $\mathrm{BMI}$ and serum testosterone were negatively
TABLE 6 Multivariable analysis biochemical factors associated with male infertility

\begin{tabular}{|c|c|c|c|c|c|}
\hline Factors & Beta & Wald & $\begin{array}{l}\text { Adjusted } \\
\text { Prevalence } \\
\text { Ratio (PR) }\end{array}$ & $95 \% \mathrm{Cl}$ & $p$ Value \\
\hline Leptin (ng/ml) & -0.007 & 0.383 & 0.993 & $0.970-1.016$ & 0.536 \\
\hline $\mathrm{FSH}(\mathrm{mlU} / \mathrm{ml})$ & 0.095 & 2.045 & 1.099 & $0.966-1.251$ & 0.153 \\
\hline Testosterone (ng/ml) & -0.003 & 0.002 & 0.997 & $0.875-1.137$ & 0.967 \\
\hline FSH $\times$ Testosterone & -0.054 & 12.894 & 0.948 & $0.920-0.976$ & $<0.001^{*}$ \\
\hline
\end{tabular}

Note. After adjusting, age, BMI, body fat percentage.

* Significant at $p$ value $<0.1$ 
correlated and a similar correlation has also been reported by other studies (Farooq et al., 2013; Zohdy, Kamal, \& Ibrahim, 2007).

Our study has shown a significant decrease in FSH, LH testosterone and SHBG levels among infertile males as compared to fertile males; results are similar to another study (Farooq et al., 2013). This may be because both physical and nutritional support to the developing germ cells is provided by sertoli cells through direct contact, as a developing germ cell adheres to sertoli cells (Martins et al., 2015). Sertoli cell function is mainly regulated by testosterone; thus, decreased testosterone affects spermatids and decreases sperm counts (Palmer, Bakos, Fullston, \& Lane, 2012). However, Inhibin B, FSH/LH ratios and SHBG levels are also involved in the regulation of sertoli cell function (Teerds, De Rooij, \& Keijer, 2011). Hence, a decrease in FSH, LH testosterone and SHBG levels among infertile males can be explained by the role of hormones in spermatogenesis.

Our results showed that serum leptin level is not directly related to infertility. However, serum FSH, LH, testosterone and SHBG were significantly lower in infertile subjects. Additionally, the majority of the infertile subjects were obese and had increased BF\%. However, the exact underlying mechanism is still uncovered. It has been suggested in the literature that leptin and its receptors can directly regulate the metabolic condition of sertoli cells, thus influencing spermatogenesis (Martins et al., 2015), and this could be one of the possible links between male infertility and obesity. The oxidative stress, as well as hormonal and metabolic changes, increases with adiposity in infertile men; however, infertility could recover if adiposity is treated adequately in infertile men (Lozano-Hernández, Gualdrón, Camejo, Velasco, \& Villavicencio, 2017).

There are a few limitations to our study. It is a single-centred study. But since it has a huge load of infertile couples seeking infertility treatment as compared to the other infertility centres, we can generalise our results to patients presenting at other centres in Pakistan. Moreover, it was a cross-sectional study and patients' samples were collected only once. Furthermore, it is also possible that the vast age range could have compromised some of the reproductive indices. However, follow-up studies should be done in the future to establish temporality.

\section{5 | CONCLUSIONS}

Serum leptin levels did not differ significantly in the fertile and infertile groups, and no association was found with infertility. Furthermore, male obesity was found to be associated with infertility with the decrease in levels of sex hormones.

It is thus recommended to disseminate awareness about lifestyle modifications to counteract obesity/infertility as a serious public health problem in developing and developed countries. This would help in the improvement of obesity parameters, which would decrease the chances of male infertility and improve the health of the offspring.

However, there is need for further exploration of the causes of infertility in obese infertile males.

\section{ACKNOWLEDGEMENT}

We are thankful to all the participants of this study for their cooperation in giving their semen and blood samples.

\section{CONFLICT OF INTEREST}

The author(s) declare no potential conflict of interests with respect to the research, authorship and publication of this article.

\section{ORCID}

Rehana Rehman (iD http://orcid.org/0000-0001-9730-5553

\section{REFERENCES}

Agarwal, A., Mulgund, A., Hamada, A., \& Chyatte, M. R. (2015). A unique view on male infertility around the globe. Reproductive Biology and Endocrinology, 13(1), 37. https://doi.org/10.1186/ s12958-015-0032-1

Agarwal, A., Virk, G., Ong, C., \& du Plessis, S. S. (2014). Effect of oxidative stress on male reproduction. World Journal of Men's Health, 32(1), 1-17. https://doi.org/10.5534/wjmh.2014.32.1.1

Akinloye, O., \& Truter, E. J. (2011). A review of management of infertility in Nigeria: Framing the ethics of a national health policy. International Journal of Women's Health, 3, 265. https://doi.org/10.2147/IJWH. S20501

Alam, F., Khan, T., \& Rehman, R. (2018). Stress of infertility: Can the couple cope? Journal of the Pakistan Medical Association, 68(4), 679-680.

Almabhouh, F. A., Osman, K., Ibrahim, S. F., Gupalo, S., Gnanou, J., Ibrahim, E., \& Singh, H. J. (2017). Melatonin ameliorates the adverse effects of leptin on sperm. Asian Journal of Andrology, 19(6), 647. https://doi.org/10.4103/1008-682X.183379

Almabhouh, F., Osman, K., Siti Fatimah, I., Sergey, G., Gnanou, J., \& Singh, H. (2015). Effects of leptin on sperm count and morphology in Sprague-Dawley rats and their reversibility following a 6-week recovery period. Andrologia, 47(7), 751-758. https://doi.org/10.1111/ and.12325

Almabhouh, F., \& Singh, H. (2018). Adverse effects of leptin on histoneto-protamine transition during spermatogenesis are prevented by melatonin in Sprague-Dawley rats. Andrologia, 50(1), e12814. https:// doi.org/10.1111/and.12814

Aquila, S., Gentile, M., Middea, E., Catalano, S., Morelli, C., Pezzi, V., \& Ando, S. (2005). Leptin secretion by human ejaculated spermatozoa. Journal of Clinical Endocrinology and Metabolism, 90(8), 4753-4761. https://doi.org/10.1210/jc.2004-2233

Chambers, T., \& Richard, R. (2015). The impact of obesity on male fertility. Hormones, 14(4), 563-568. https://doi.org/10.14310/ horm.2002.1621

Dalamaga, M., Chou, S. H., Shields, K., Papageorgiou, P., Polyzos, S. A., \& Mantzoros, C. S. (2013). Leptin at the intersection of neuroendocrinology and metabolism: Current evidence and therapeutic perspectives. CellMetabolism, 18(1), 29-42. https://doi.org/10.1016/j. cmet.2013.05.010

Dayer, D., Nikbakht, R., \& Elyaderani, M. K. (2013). Comparison of leptin concentrations between infertile women with polycystic ovary syndrome and fertile women. Iranian Journal of Reproductive Medicine, 11(12), 1033.

Einollahi, N., Dashti, N., Emamgholipour, S., Zarebavani, M., SedighiGilani, M. A., \& Choobineh, H. (2016). Evidence for alteration in serum concentrations of leptin in infertile men categorized based on. BMI. Clin, Lab, 59. https://doi.org/10.7754/Clin.Lab.2016.160516 
Farooq, R., Lutfullah, S., \& Ahmed, M. (2014). Serum leptin levels in obese infertile men and women. Pakistan Journal of Pharmaceutical Sciences, 27(1), 67-71.

Farooq, R., Ullah, S. L., \& Ishaq, H. (2013). Relation of serum leptin with sex hormones of obese infertile men and women. Journal of Applied Pharmaceutical Science, 3(1), 60-65.

Hammoud, A. O., Gibson, M., Peterson, C. M., Meikle, A. W., \& Carrell, D. T. (2008). Impact of male obesity on infertility: A critical review of the current literature. Fertility and Sterility, 90(4), 897-904. https:// doi.org/10.1016/j.fertnstert.2008.08.026

Hausman, G. J., Barb, C. R., \& Lents, C. A. (2012). Leptin and reproductive function. Biochimie, 94(10), 2075-2081. https://doi.org/10.1016/j. biochi.2012.02.022

Hodžić, A., Ristanović, M., Zorn, B., Tulić, C., Maver, A., Novaković, I., ... Peterlin, B. (2017). Genetic variation in leptin and leptin receptor genes as a risk factor for idiopathic male infertility. Andrology, 5(1), 70-74. https://doi.org/10.1111/andr.12295

Hofny, E. R., Ali, M. E., Abdel-Hafez, H.Z., Kamal, E.-E.-D., Mohamed, E. E., El-Azeem, H. G. A., \& Mostafa, T. (2010). Semen parameters and hormonal profile in obese fertile and infertile males. Fertility and Sterility, 94(2), 581-584. https://doi.org/10.1016/j.fertnstert.2009.03.085

Jahan, S., Bibi, R., Ahmed, S., \& Kafeel, S. (2011). Leptin levels in infertile males. Journal of the College of Physicians and Surgeons Pakistan, 21, 393-397.

Kahn, B. E., \& Brannigan, R. E. (2017). Obesity and male infertility. Current Opinion in Urology, 27(5), 441-445. https://doi.org/10.1097/ MOU.0000000000000417

Katib, A. (2015). Mechanisms linking obesity to male infertility. Central European Journal of Urology, 68(1), 79.

Lampiao, F., Agarwal, A., \& du Plessis, S. S. (2009). The role of insulin and leptin in male reproduction. Archives of Medical Science Special Issues, 5(1A), S48-S54.

Lazzer, S., Boirie, Y., Meyer, M., \& Vermorel, M. (2003). Evaluation of two foot-to-foot bioelectrical impedance analysers to assess body composition in overweight and obese adolescents. British Journal of Nutrition, 90(05), 987-992. https://doi.org/10.1079/BJN2003983

Leisegang, K., Bouic, P. J., Menkveld, R., \& Henkel, R. R. (2014). Obesity is associated with increased seminal insulin and leptin alongside reduced fertility parameters in a controlled male cohort. Reproductive Biology and Endocrinology, 12(1), 34. https://doi. org/10.1186/1477-7827-12-34

Lozano-Hernández, R., Gualdrón, J., Camejo,M., Velasco,J.,\&Villavicencio, A. (2017). Markers of accessory glands and seminal parameters in infertile men with overweight and obesity. Journal of Metabolic Syndrome, 6(229). https://doi.org/10.4172/2167-0943.1000229

Martins, A. D., Moreira, A. C., Sá, R., Monteiro, M. P., Sousa, M., \& Carvalho, R. A. (2015). Leptin modulates human Sertoli cell acetate production and glycolytic profile: A novel mechanism of obesity-induced male infertility? Biochimica Et Biophysica Acta, 1852, https:// doi.org/10.1016/j.bbadis.2015.06.005

Martins, A. D., Moreira, A. C., Sá, R., Monteiro, M. P., Sousa, M., Carvalho, R. A., ... Alves, M. G. (2015). Leptin modulates human Sertoli cells acetate production and glycolytic profile: A novel mechanism of obesity-induced male infertility? Biochimica Et Biophysica Acta (BBA)-Molecular Basis of Disease, 1852(9), 1824-1832. https://doi. org/10.1016/j.bbadis.2015.06.005

Menkveld, R., Wong, W. Y., Lombard, C. J., Wetzels, A. M., Thomas, C. M., Merkus, H. M., \& Steegers-Theunissen, R. P. (2001). Semen parameters, including WHO and strict criteria morphology, in a fertile and subfertile population: An effort towards standardization of invivo thresholds. Human Reproduction, 16(6), 1165-1171. https://doi. org/10.1093/humrep/16.6.1165

Palmer, N. O., Bakos, H. W., Fullston, T., \& Lane, M. (2012). Impact of obesity on male fertility, sperm function and molecular composition. Spermatogenesis, 2(4), 253-263. https://doi.org/10.4161/ spmg. 21362

Park, H.-K., \& Ahima, R. S. (2015). Physiology of leptin: Energy homeostasis, neuroendocrine function and metabolism. MetabolismClinical and Experimental, 64(1), 24-34. https://doi.org/10.1016/j. metabol.2014.08.004

Stewart, T., Liu, D., Garrett, C., Jørgensen, N., Brown, E., \& Baker, H. (2009). Associations between andrological measures, hormones and semen quality in fertile Australian men: Inverse relationship between obesity and sperm output. Human Reproduction, 24(7), 1561-1568. https://doi.org/10.1093/humrep/dep075

Tafvizi, F., \& Masomi, M. (2016). Comparison of serum leptin level in women with unexplained infertility and fertile women in Iran. Journal of Obstetrics and Gynecology of India, 66(1), 466-470. https://doi. org/10.1007/s13224-016-0843-9

Teerds, K., De Rooij, D., \& Keijer, J. (2011). Functional relationship between obesity and male reproduction: From humans to animal models. Human Reproduction Update, 17(5), 667-683. https://doi. org/10.1093/humupd/dmr017

Tunc, O., Bakos, H., \& Tremellen, K. (2011). Impact of body mass index on seminal oxidative stress. Andrologia, 43(2), 121-128. https://doi. org/10.1111/j.1439-0272.2009.01032.x

Von Sobbe, H. U., Koebnick, C., Jenne, L., \& Kiesewetter, F. (2003). Leptin concentrations in semen are correlated with serum leptin and elevated in hypergonadotrophic hypogonadism. Andrologia, 35(4), 233237. https://doi.org/10.1046/j.1439-0272.2003.00565.x

Wang, X., Zhang, X., Hu, L., \& Li, H. (2018). Exogenous leptin affects sperm parameters and impairs blood testis barrier integrity in adult male mice. Reproductive Biology and Endocrinology, 16(1), 55. https:// doi.org/10.1186/s12958-018-0368-4

Who, E. C. (2004). Appropriate body-mass index for Asian populations and its implications for policy and intervention strategies. Lancet, 363, 157-163.

Wright, C., Milne, S., \& Leeson, H. (2014). Sperm DNA damage caused by oxidative stress: Modifiable clinical, lifestyle and nutritional factors in male infertility. Reproductive Biomedicine Online, 28(6), 684-703. https://doi.org/10.1016/j.rbmo.2014.02.004

Zahid, N., Saleem, S., Azam, I., \& Moatter, T. (2015). Association of obesity with infertility among Pakistani men: A case control study. Open Journal of Epidemiology, 5(03), 204. https://doi.org/10.4236/ ojepi.2015.53025

Zohdy, W., Kamal, E. E., \& Ibrahim, Y. (2007). Androgen deficiency and abnormal penile duplex parameters in obese men with erectile dysfunction. Journal of Sexual Medicine, 4(3), 797-808. https://doi. org/10.1111/j.1743-6109.2007.00499.x

How to cite this article: Amjad S, Baig M, Zahid N, Tariq S, Rehman R. Association between leptin, obesity, hormonal interplay and male infertility. Andrologia. 2019;51:e13147. https://doi.org/10.1111/and.13147 